\title{
Evaluation of reflective painting of the roof and artificial ventilation on performance and carcass yield of broilers
}

\author{
Roberta Passini ${ }^{1}$, Maria Angélica Gonçalves de Araújo², Eduardo Alves de Almeida ${ }^{3}$, Vinícius \\ Melo Yasuda ${ }^{4}$
}

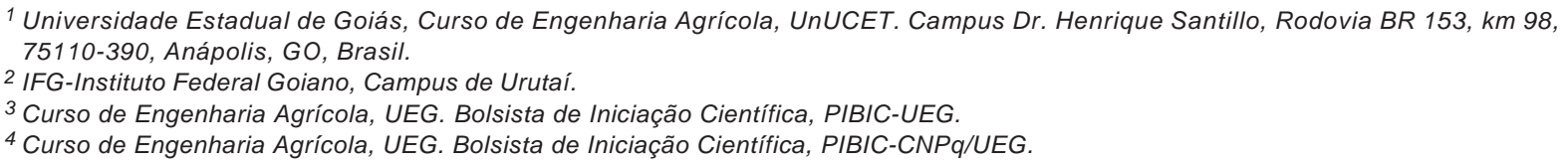

\begin{abstract}
This study was developed with the objective of evaluating reflective paint on covering and artificial ventilation on performance of broilers (males and females). A randomized design with a $2 \times 2 \times 2$ factorial arrangement of treatments was used, as follows: 2 external management systems (coverage with and without reflective paint), 2 internal management systems (with and without artificial ventilation) and 2 sexes (male and female), totalizing 8 treatments. A total of 480 1-day old chicks of the Cobb strain were distributed randomly, according to sex, to treatments. Each treatment consisted of 4 pens - two pens for males and two for females - with 30 birds each. Six birds/pen were sampled. The studies were conducted at IFG-Urutaí Campus. For the performance evaluation, average weight, feed intake and mortality rate were measured weekly. There are differences between the performance of males and females, with males having greater weight gain and increased feed intake compared with females. The use of environmental changes, such as reflective paint or artificial ventilation, fosters weight gain and feed intake by broilers. There is positive effect of combined use of reflective paint and artificial ventilation in the feed intake of birds.
\end{abstract}

Key Words: aviculture, poultry environment, thermal comfort

\section{Introduction}

The thermal stress caused by the environment has influence on animal productivity, mainly by altering its heat exchange with the environment, which has direct effects on feed consumption, weight gain, and, therefore, animal metabolism and nutrient requirements (Oliveira et al., 2000).

In order to provide thermal comfort in their internal environment, poultry houses need an adequate project, which must take into consideration the use of appropriate construction materials, their geographical orientation and housing capacity (Rodrigues et al., 2009). One must prioritize ways to re-adapt pre-existent infra-structure and/or new housing projects which are based on the welfare of animals (Tinôco, 2001). The costs/benefit ratio should be considered as well, since the investments needed to re-adapt such structures are significantly high (Rodrigues et al., 2009).

Fiber-cement roofs cleaned periodically and painted white can be more effective in their capacity to absorb and reflect heat when compared with ceramic tiles (Silva, 2001). The use of the white color in external surfaces can reduce the housing internal temperature in up to $9{ }^{\circ} \mathrm{C}$ during times of the day when solar radiation is at its peak (Sarmento et al., 2005).

According to Tinôco (2001), in regions with humid and hot tropical climate during most part of the year, the architectural responses to heat should involve adaptations and aiding systems which seek the mitigation of solar radiation effects as well as abundant and constant ventilation. Ventilation is needed to eliminate the excessive humidity of the internal environment and bedding, to promote air renovation, and also to eliminate odors.

Therefore, the objective of this study was to evaluate the effects of environmental modifications, such as reflective painting of roofs and artificial ventilation, on performance, feed intake, feed conversion and carcass yield of male and female broilers.

\section{Material and Methods}

The experiment was conducted at Instituto Federal Goiano (IFG) - Urutaí Campus, located in the Geraldo Silva Nascimento highway, km 2.5, in the rural area of Urutaí, Goiás, Brazil, from December 2009 to January 2010. The 
region is located at $744 \mathrm{~m}$ of altitude, $17^{\circ} 27^{\prime} 49^{\prime \prime S}$ latitude and $48^{\circ} 12^{\prime}$ 06"W longitude, under Cwa climate classification (Köppen, 1936).

A poultry house geographically oriented at $32^{\circ}$ northwest, with $21.25 \mathrm{~m}$ length by $8.00 \mathrm{~m}$ width, walls of $0.46 \mathrm{~m}$ height, internal ceiling height of $3.0 \mathrm{~m}$ and roof of fiber-cement tiles was used for the experiment. The floor was made of concrete, the sides were protected by galvanized wire mesh and blue canvas drapes managed manually. The side walls were semi-open, made of bricks and painted white.

All treatment pens were in the same poultry house. Microclimates were maintained by isolation with double plastic tarps, which allowed the division of the poultry house into four parts, prepared for experimental comparison.

The reflective painting used white latex paint, applied on the external surface of the roof for two times: after the washing and cleaning of the fiber-cement tiles. For the artificial ventilation of the poultry house, axial ventilators model VLA-1000, with 15,000 $\mathrm{m}^{3} / \mathrm{h}$ flow and $1120 \mathrm{rpm}$ were used.

The experimental design was the completely randomized, in subdivided plots, with treatments in a $2 \times 2 \times 2$ factorial arrangement, with 2 management systems (roof with and without white reflective painting), 2 internal managements (with and without artificial ventilation), and two sexes (males and females), in a total of 8 treatments.

Four hundred and eighty one-day old chicks from the Cobb Strain were distributed randomly, according to sex, over the treatments. Each treatment was composed of 4 pens - two pens for males and two pens for females, with 30 chicks per pen. Six animals from each pen were sampled, providing twelve repetitions for males and twelve repetitions for females in each treatment.

The experimental pens were of $1.30 \mathrm{~m} \times 2.18 \mathrm{~m}$, with populational density of 10.6 chicks per square meter. Chicks were homogenized by weight, with initial average weights calculated for further evaluation of performance.

During the experimental period, broiler management was conducted according to recommended techniques for broiler production. The bedding was composed of wood shavings, with minimum height of $10 \mathrm{~cm}$. The initial vaccination took place at the incubatory for Marek's and Gumboro diseases.

Broilers received a bran concentrate, mixed at the meal plant of IFG, according to the nutrition guide of the Cobb Strain (Ribeiro, 2006). Two types of concentrate were used ad libitum: initial concentrate (1 to 28 days), with metabolizable energy levels of 3,000 kcal kg-1 and 20\% crude protein; and growth concentrate (29 to 42 days), with metabolizable energy levels of 3,000 kcal kg-1 and 18\% crude protein, on a dry matter basis.

Water was offered ad libitum, in pendulum-type drinkers. Until ten days of age, chicks received artificial heat through $150 \mathrm{~W}$ incandescent lamps installed in every pen separately. The poultry house received artificial light during night time, from 6 p.m. to 8 a.m., provided by $12100 \mathrm{~W}$ incandescent lamps, covering a total area of $108 \mathrm{~m}^{2}$.

For evaluation of the broiler performance, the average initial weight was calculated as $46 \mathrm{~g}$ per chick. At the end of the 42-day cycle, six broilers per pen were sampled in order to measure the final weight and, therefore, to calculate the total weight gain (TWG) by difference during the experimental period. Feed intake, in kilograms of dry matter $\left(\mathrm{kg} \mathrm{DM}^{-1}\right.$ ), was measured at 42 days, through weighing of the feed offered and its left overs. Feed conversion was also calculated (kg DM concentrate/kg TWG).

At the end of the experimental period, broilers were fasted for 8 hours, slaughtered and later identified through colored plastic braces according to the respective treatments. Once identified, the animals were weighted and processed according to slaughter normal procedures.

After slaughtering, carcasses were chilled without feet, head and eatable internal organs. Carcasses were weighted on digital scales with maximum capacity of $6 \mathrm{~kg}$ and $2 \mathrm{~g}$ precision. The chilled carcass yield (CCY) was calculated by the ratio between fasted live weight and chilled carcass weight according to the formula: \% CCY = (chilled carcass weight $\times 100$ )/fasted live weight.

Data was analyzed through Statistical Analysis Software (SISVAR 5.1) with conduction of variance analyses. When differences were observed, Tukey test was utilized for comparison of means, with significance level set at $5 \%$.

\section{Results and Discussion}

Statistical differences $(\mathrm{P}<0.05)$ were observed in total weight for all three main effects: sex, reflective painting and artificial ventilation (Table 1). No differences were observed for the interactions between the main studied effects. Sex influenced the weight gain so that males presented higher weight gain when compared with females. The weight gains were 2,363 and 2,157 kg for males and females, respectively $(\mathrm{P}<0.01)$. As expected, the use of reflective painting increased total weight gain, with observed values of 2,333 and 2,187 kg, respectively, for broilers subjected to the environment with white-painted roof and without it $(\mathrm{P}<0.01)$. 
Table 1 - Average total weight gain (TWG, in kg), dry matter intake (DMI, in kg) and feed conversion (FC), observed in the different treatments, with respective coefficients of variation and statistical probabilities

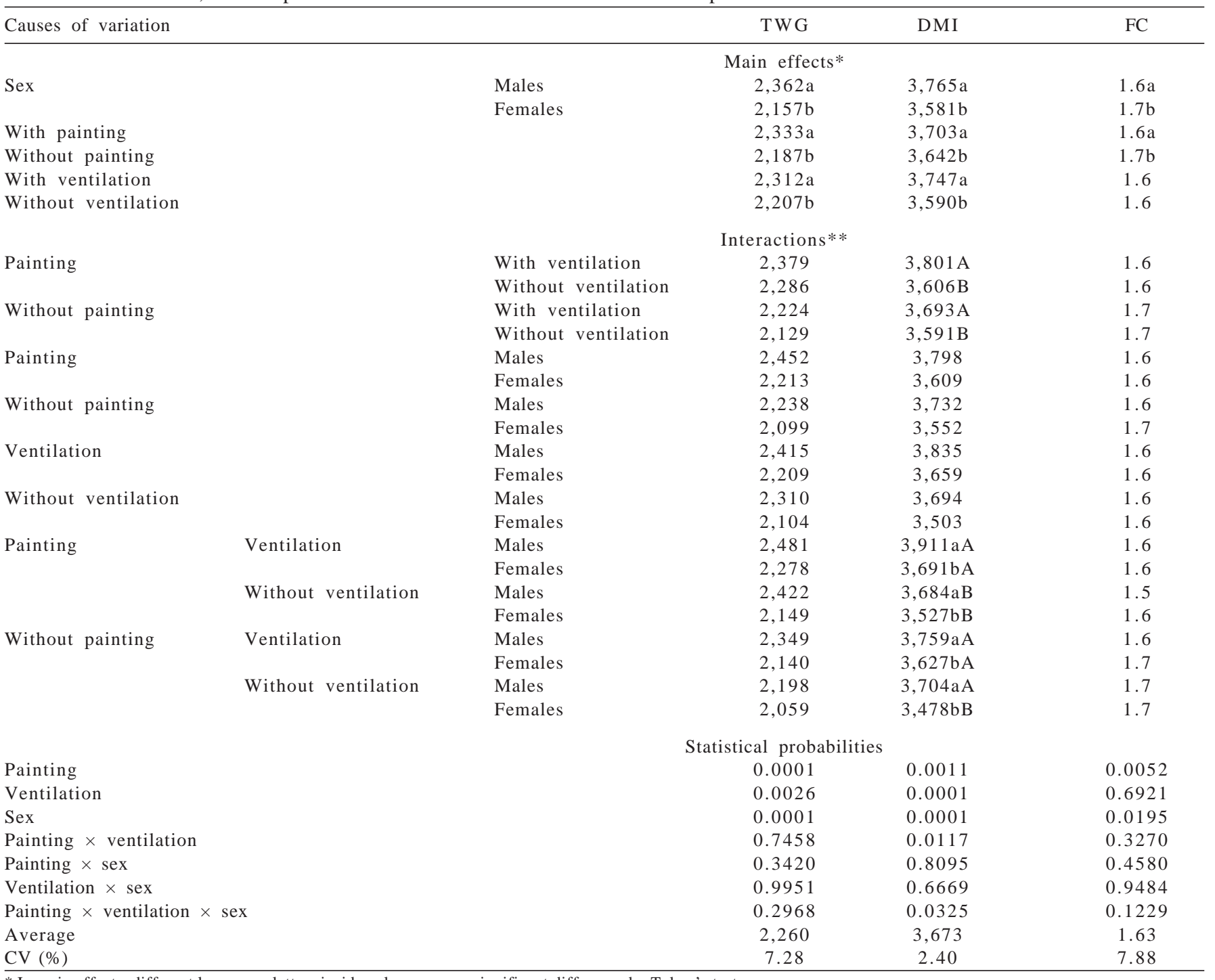

* In main effects, different lowercase letters inside columns mean significant difference by Tukey’s test.

** In interactions, different lowercase letters inside columns mean significant difference by Tukey's test, representing the effects of sex inside the other factors. Capital letters inside columns mean significant difference by Tukey's test, representing the effects of ventilation inside the other factors.

Higher weight gains $(\mathrm{P}<0.01)$ were observed in the broilers kept under artificial ventilation (2,312 kg) when compared with broilers kept without artificial ventilation (2,207 kg).

The main sex effect influenced all other factors, with higher values $(\mathrm{P}<0.01)$ observed in male broilers when compared with female broilers in all studied interactions, as preconized in the literature.

Similar results were observed by Gomes et al. (2009), when studying the effects of diets with different levels of Zinc during the growing phase (22 to 42 days of age) of male broilers. The authors noticed that male broilers presented better weight gain, feed intake and feed conversion than female broilers subjected to the same treatments. Carvalho et al. (2009), also observed better performance of male broilers during production period of 1 to 42 days, when compared with female broilers receiving the same feeding treatments based on corn meal and soybean meal.

In the total dry matter intake (DMI) analysis for the period of 0 to 42 days, there were effects of the main factors as well as effects of the interaction between reflective painting and artificial ventilation $(\mathrm{P}<0.05)$, and also interaction between reflective painting $\times$ artificial ventilation $\times \operatorname{sex}(\mathrm{P}<0.05)($ Table 1$)$. The DMI was higher $(\mathrm{P}<0.01)$ in male broilers $(3,765 \mathrm{~kg})$ when compared with females $(3,581 \mathrm{~kg})$; in pens with reflective painting $(3,703 \mathrm{~kg})$ when compared with pens without it (3,642 kg); and in pens with artificial ventilation $(3,747 \mathrm{~kg})$ when compared with pens without it $(3,590 \mathrm{~kg})(\mathrm{P}<0.01)$.

In the analysis of the interaction between use of reflective painting and artificial ventilation, it was observed 
that the utilization of these tools combined promoted higher feed intake when compared with the pens which did not have reflective painting or artificial ventilation $(\mathrm{P}<0.05)$. The DMI in the treatment with white reflective painting and artificial ventilation was $5.5 \%$ higher than the DMI in the treatment without painting and ventilation.

The combined use of white reflective painting and artificial ventilation promoted numerically higher weight gains, even though no significant differences were verified, as observed by Sarmento et al. (2005), when comparing the efficiency of poultry houses with and without the reflective painting of roofs and the use of artificial ventilation. The authors did not observe significant differences between treatments in parameters such as WG, DMI and FC.

When considering the interactions between painting $x$ ventilation $\times$ sex, it is possible to note the positive effects of environmental modifications aiming at the welfare of animals in both male and female broilers (Table 1). For males, the combined use of painting and ventilation resulted in DMI of 3,911 kg broiler-1 in the total period, when compared with the $3,684 \mathrm{~kg}$ broiler $^{-1}$, also for males, kept in the pens with painting but without ventilation $(\mathrm{P}<0.05)$. Similar results were observed for females, which presented DMI of 3,691 $\mathrm{kg} /$ broiler and 3,528 kg/broiler, in the pens with reflective painting with and without ventilation, respectively $(\mathrm{P}<0.05)$.

In the pens without reflective painting, the use of artificial ventilation was positive for the female broilers, but not for the male broilers. An increase of $4 \%$ in the DMI of female broilers in pens with ventilation was observed, when compared with pens without ventilation $(\mathrm{P}<0.05)$. However, no significant differences were observed in the DMI of male broilers kept in the same treatments.

The weight gain and feed intake results observed reflected in the feed conversion values so that only effects of the sex and reflective painting main factors were significantly different for the calculated parameter $(\mathrm{P}<0.05)$.

As for feed conversion, the best values were observed for males (1.6), when compared with females (1.7) $(\mathrm{P}<0.05)$. Similar results were observed in the pens with use of reflective painting (1.6), when compared with values observed for the pens without it (1.7), with no effects of interactions observed between the factors for the studied parameter.

The production guidelines for broilers from the Cobb strain adopts FC of 1.77 as standard value for feed conversion of broilers at 42 days of age (Ribeiro, 2006). Therefore, the values of FC observed in this experiment were positive, facing the environment modifications studied. The standard average weight for broilers at 42 days of age should be of 2,801 kg. Based on these guideline values, even with the combined use of painting and ventilation, the live weight of the broilers in this experiment was below the values that the animal genetics would be able to express, theoretically.

The fact that no significant differences were observed for the effects of the interactions between reflective painting and artificial ventilation on weight gain can be related to the geographical orientation of the experimental poultry house at $32^{\circ} \mathrm{NO}$, which means it was not oriented on an longitudinal east-west axis, as recommended in the literature. According to Rodrigues et al. (2009), the eastwest axis orientation favors the control of heat and solar radiation exposition during the summer, because it enables the poultry house to have a smaller area exposed to incident solar radiation. Ferreira (2005) also explains the importance of the east-west axis orientation for poultry houses, mainly because it mitigates the direct incidence of solar radiation on the broilers, causing thermal discomfort, hence the observation of the positive effects of only the reflective painting or the artificial ventilation, with failure to report the added positive effects of both environment modifications studied, seen in other studies.

For fasted live weight of broilers, there was a significant effect for the main factors $(\mathrm{P}<0.05)$ (Table 2$)$. It was observed that male broilers presented higher fasted live weight (2,291 kg/broiler) when compared with females (2,129 kg/broiler). The fasted live weight before slaughter reflects the results for the weight gain of animals throughout the cycle, reinforcing the theory that male broilers have higher weight gain than female broilers.

There was a significant difference for the use of reflective painting and artificial ventilation $(\mathrm{P}<0.05)$, with the reflective painting promoting a higher fasted live weight at the end of the cycle $(2,259 \mathrm{~kg} /$ broiler $)$ when compared with broilers kept in the pens without the reflective painting (2,160 kg/broiler) (Table 2$)$. The same trends were seen in the treatments with and without artificial ventilation. For that matter, the use of artificial ventilation promoted a higher fasted live weight in the broilers at the end of the cycle $(2,259 \mathrm{~kg} /$ broiler $)$ when compared with the performance of broilers kept under no use of artificial ventilation (2,160 kg/broiler).

Significant differences $(\mathrm{P}<0.05)$ were observed in the interaction of the factors reflective painting and artificial ventilation for fasted live weight. Broilers kept in pens with the combined use of the environment modifications showed higher fasted live weight at the end of the cycle (2,355 kg/broiler) than the broilers in the other treatments, 
Table 2 - Average fasted live weight (FLW/kg), chilled carcass weight (CCW/kg) and chilled carcass yield (CCY, in \%), with respective coefficients of variation and statistical probabilities

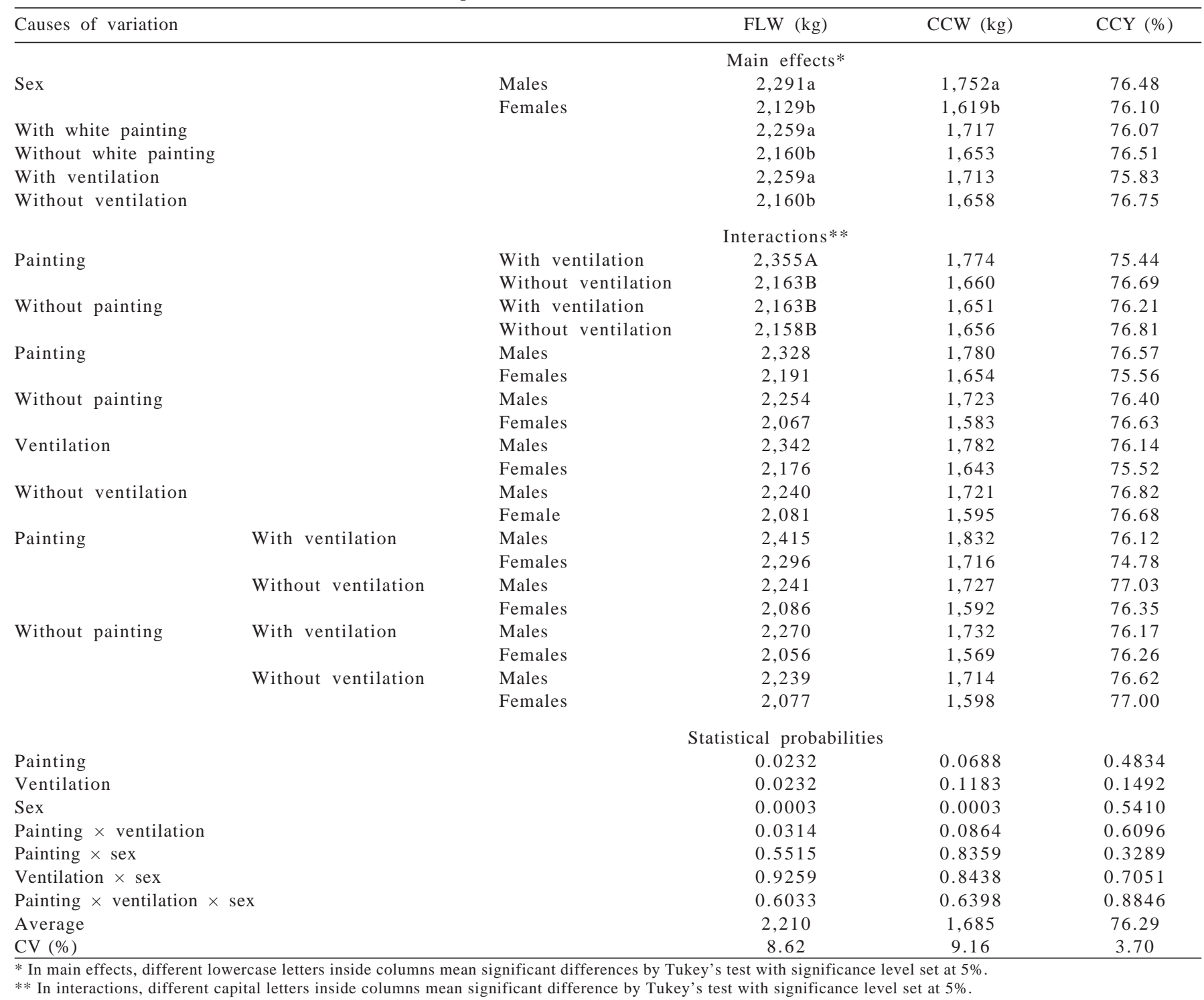

which presented an average fasted live weight of 2,163 kg/ broiler (Table 2).

As for carcass weight, significant difference was observed only for the main effect sex $(\mathrm{P}<0.01)$, in which male broilers had higher chilled carcass weight (1,752 kg/broiler) than female broilers (1,619 kg/broiler). It was verified that both reflective painting and artificial ventilation provided a numerical increase in the values of chilled carcass weight when compared with the values obtained from animals kept in pens without reflective painting or artificial ventilation, even though no significant differences were observed.

No significant differences were observed between interactions in the chilled carcass weight $(\mathrm{P}>0.05)$. However, the use of reflective painting combined with artificial ventilation provided values for chilled carcass weight numerically higher $(1,774 \mathrm{~kg} /$ broiler $)$ than those observed in values obtained from broilers kept under reflective painting and without artificial ventilation (1,660 kg/broiler).

There were no significant differences for chilled carcass yield $(\mathrm{P}>0.05)$, in any of the studied factors or its interactions. Such fact can be explained by how the chilled carcass yield parameter is calculated. It is related to the carcass weight without eatable internal organs, feet and head, and to the fasted live weight of the broilers. Broilers with heavier fasted live weight have a tendency to present higher chilled carcass weight. Broilers which are lighter before slaughter have a tendency to present smaller values for chilled carcass weight. Hence, when relating the live weight of animals with their carcass weight, there is a dissolution of such values, which brings values of chilled carcass yield practically constant, regardless of sex or production environment. 
Broilers presented an average chilled carcass yield at 42 days of $76.29 \%$. These values were higher than those observed by Garcia et al. (2008) and Carvalho et al. (2009), who, when studying the carcass yield of broilers, obtained carcass yield at the end of the cycle of $74.78 \%$ and $72.7 \%$, respectively.

\section{Conclusions}

The use of environment modifications, such as reflective painting or artificial ventilation had a positive effect on broiler weight gain. There was also a positive effect of the use of the combined tools on feed intake. Although male broilers presented higher live weight and higher carcass weight when compared with female broilers, carcass yield was not significantly different between the sexes or environments studied.

\section{References}

CARVALHO, J.C.C.; BERTECHINI, A.G.; FASSANI, E.J. et al. Desempenho e características de carcaça de frangos de corte alimentados com dietas à base de milho e farelo de soja suplementados com complexos enzimáticos. Revista Brasileira de Zootecnia, v.38, n.2, p.292-298, 2009.
FERREIRA, R.A. Maior produção com melhor ambiente para aves, suínos e bovinos. Viçosa, MG: Aprenda Fácil, 2005. 371p.

GARCIA, R.; CALDARA, F.; VARGAS JUNIOR, F. et al. Jejum alimentar pré-abate no rendimento e qualidade de carcaça de frangos de corte tipo griller. Agrarian, v.1, n.2, p.113-121, 2008.

GOMES, P.C.; RIGUEIRA, D.C.M.; BRUMANO, G. et al. Níveis nutricionais de zinco para frangos de corte machos e fêmeas nas fases de crescimento e terminação. Revista Brasileira de Zootecnia, v.38, n.9, p.1719-1725, 2009.

KÖPPEN, W. Das geographisca system der klimate. Berlin: Gebruder Borntraeger. 1936. p.1-44.

OLIVEIRA, J. E.; SAKOMURA, N.K.; FIGUEIREDO, A.N. et al. Efeito do Isolamento térmico de telhado sobre o desempenho de frangos alojados em diferentes densidades. Revista Brasileira de Zootecnia, v.29, n.5, p.1427-1434, 2000.

RIBEIRO, R. Manual do frango de corte. Granja Planalto. Manual Técnico (revisado, 18 set. 2006). Available at: $<$ http://www.granjaplanalto.com.br/MANUAL_MOD\%20REV. \%2003_18_09_06.pdf $>$. Accessed on: Sept. 20, 2010.

RODRIGUES, V.C.; SILVA, I.J.O.; NASCIMENTO, S.T. et al. Instalações avícolas do estado de São Paulo - Brasil: Os principais pontos críticos quanto ao bem estar e conforto térmico animal. THESIS, v.5, n.11, p.24-30, 2009.

SARMENTO, L.G.V.; DANTAS, R.T.; FURTADO, D.A. et al. Efeito da pintura externa do telhado sobre o ambiente climático e o desempenho de frangos de corte. Revista Agropecuária Técnica, v.26, n.2, p.152-159, 2005.

SILVA, I.J.O. Ambiência na produção de aves em clima quente. Jaboticabal: Sociedade Brasileira de Engenharia Agrícola, 2001. v.1, 200p.

TINÔCO, I.F.F. Avicultura industrial: novos conceitos de materiais, concepções e técnicas construtivas disponíveis para galpões avícolas brasileiros. Revista Brasileira de Ciência Avícola, v.3, n.1, p.1-26, 2001. 